\title{
$\mathbf{R b}$ induces a proliferative arrest and curtails Brn-2 expression in retinoblastoma cells
}

\author{
David Cobrinik*1,2, Richard O Francis ${ }^{3}$, David H Abramson ${ }^{2,4}$ and \\ Thomas C Lee Le, $^{1,5}$
}

\begin{abstract}
Address: ${ }^{1}$ Margaret M. Dyson Vision Research Institute, Weill Medical College of Cornell University, New York, NY 10021, USA, ${ }^{2}$ Department of Ophthalmology, Weill Medical College of Cornell University, New York, NY 10021, USA, ${ }^{3}$ Department of Pathology, Columbia University College of Physicians and Surgeons, New York, NY 10032, USA, ${ }^{4}$ Ophthalmic Oncology Service, Memorial Sloan-Kettering Cancer Center, New York, NY 10021, USA and ${ }^{5}$ Division of Ophthalmology, Department of Surgery, Childrens Hospital Los Angeles, Los Angeles, CA, USA
\end{abstract}

Email: David Cobrinik* - dec2014@med.cornell.edu; Richard O Francis - rof3@columbia.edu; David H Abramson - Abramsod@mskcc.org; Thomas C Lee - tcl2002@med.cornell.edu

* Corresponding author

Published: 12 December 2006

Molecular Cancer 2006, 5:72 doi:10.1/86/1476-4598-5-72
Received: 20 July 2006

Accepted: 12 December 2006

This article is available from: http://www.molecular-cancer.com/content/5/I/72

(c) 2006 Cobrinik et al; licensee BioMed Central Ltd.

This is an Open Access article distributed under the terms of the Creative Commons Attribution License (http://creativecommons.org/licenses/by/2.0), which permits unrestricted use, distribution, and reproduction in any medium, provided the original work is properly cited.

\begin{abstract}
Background: Retinoblastoma is caused by loss of the $\mathrm{Rb}$ protein in early retinal cells. Although numerous $\mathrm{Rb}$ functions have been identified, $\mathrm{Rb}$ effects that specifically relate to the suppression of retinoblastoma have not been defined.

Results: In this study, we examined the effects of restoring Rb to Y79 retinoblastoma cells, using novel retroviral and lentiviral vectors that co-express green fluorescent protein (GFP). The lentiviral vector permitted transduction with sufficient efficiency to perform biochemical analyses. Wild type $\mathrm{Rb}\left(\mathrm{Rb} \mathrm{WT}^{\mathrm{W}}\right.$ ) and to a lesser extent the low penetrance mutant $\mathrm{Rb}^{66 \mathrm{IW}}$ induced a G0/GI arrest associated with induction of P27KIPI and repression of cyclin EI and cyclin E2. Microarray analyses revealed that in addition to down-regulating E2F-responsive genes, Rb repressed expression of Brn-2 (POU3F2), which is implicated as an important transcriptional regulator in retinal progenitor cells and other neuroendocrine cell types. The repression of $B r n-2$ was a specific $\mathrm{Rb}$ effect, as ectopic p27 induced a G0/GI block, but enhanced, rather than repressed, Brn-2 expression.
\end{abstract}

Conclusion: In addition to $\mathrm{Rb}$ effects that occur in many cell types, $\mathrm{Rb}$ regulates a gene that selectively governs the behavior of late retinal progenitors and related cells.

\section{Background}

Retinoblastomas form due to the inactivation of the RB1 gene together with other genetic changes [1]. Whereas RB1 is also inactivated in other tumors, the cells that give rise to retinoblastoma are exceptionally sensitive to $\mathrm{Rb}$ loss. Individuals with bilateral retinoblastoma (and presumed germ line RB1 mutations) develop an average of five retinoblastoma foci, generally within their first 2 years $[2,3]$, but have only 1\% per year likelihood of developing all other tumor types [4]. Moreover, retinoblastoma is largely a human-specific disease. Tumors with histopathological features of retinoblastoma, including photoreceptor but not amacrine differentiation, have been reported for only two individual animals $[5,6]$ and appear not to form in response to the loss of $\mathrm{Rb}$ family proteins in mice [7-10]. 
$\mathrm{Rb}$ has numerous functions that might mediate the suppression of retinoblastoma [11]. Studies in non-retinal cells have shown that $\mathrm{Rb}$ can inhibit cell cycle progression through regulation of E2F1 and p27 Kip1 [12-14], and may induce a senescence-like response through E2F-dependent or E2F-independent mechanisms [15-17]. In addition, $\mathrm{Rb}$ promotes differentiation through interactions with several widely expressed proteins $[18,19]$, and may both promote differentiation and suppress tumorigenesis by inhibiting Ras [20]. Besides these general effects, Rb promotes osteogenic, adipogenic, thyroid, and melanocytic differentiation through interactions that are specific to the relevant cell types [21-26]. Thus, to understand how Rb suppresses retinoblastoma, it may be necessary to identify the cell type-specific functions of $\mathrm{Rb}$ in the cells that give rise to retinoblastoma tumors.

At present, the cell type that gives rise to retinoblastoma has not been identified. It was proposed that retinoblastomas arise from a primitive neuroectodermal cell [27], such as a retinal progenitor cell (RPC) or a transition cell that fails to arrest in Rb's absence during early differentiation [28]. More recent evidence suggests a possible origin from post-mitotic cone precursors [29]. However, defining Rb's tumor suppressor role in any of these cell types is problematic, as human retinal cells are poorly suited to growth and manipulation in vitro, and as Rb's tumor suppressor role may not be replicated in vivo, in mouse models. As an alternative to working with the retinoblastoma cell of origin, insight into Rb's role may be gained by examining the effects of restoring $\mathrm{Rb}$ to retinoblastoma cells. While signaling in such cells may differ to some extent from that in the cell of origin, cell type-specific retinoblastoma suppressor functions of $\mathrm{Rb}$ seem more likely to be manifested in retinoblastoma cells than in other available cell types.

The effect of restoring $\mathrm{Rb}$ to retinoblastoma cells was first examined soon after the RB1 gene was cloned. When $\mathrm{Rb}$ was restored using Murine leukemia virus (MLV)-based retroviral vectors, transduced cells were analyzed after $>4$ weeks of selection and displayed either modestly diminished proliferation $[30,31]$ or no obvious change in proliferative rate [32-35]. In contrast, when $\mathrm{Rb}$ was restored by transfer of chromosome 13 (on which RB1 resides), proliferation was clearly impaired [36]. This suggested that expression of $\mathrm{Rb}$ under its normal regulatory sequences conferred a stronger antiproliferative effect than was conferred with MLV-based vectors. However, chromosome transfer is too inefficient to be used to define Rb's acute effects, and cannot be used to compare effects of wild type and mutant Rb proteins.

To define the effects of restoring $\mathrm{Rb}$ to retinoblastoma cells, we developed retroviral and lentiviral vectors that co-express $\mathrm{Rb}$ and enhanced green fluorescent protein (GFP). As MLV-based retroviral vectors have a propensity to be silenced by trans-acting factors and DNA methylation, we used murine stem cell virus (MSCV) and lentivirus vectors that have diminished silencing $[37,38]$. Use of the GFP marker permitted the acute effects of $\mathrm{Rb}$ to be observed in the absence of antibiotic selection of transduced cells, and permitted the efficiency of transduction to be determined prior to biochemical analysis. These studies demonstrate that several of the Rb effects that have been observed in other cell types are also manifested in retinoblastoma cells. In addition, they identify an Rb-regulated gene that may have a crucial role in retinal cell proliferation.

\section{Results \\ Restoration of Rb to Y79 cells using the MSCV-GFP retroviral vector}

In initial experiments, Y79 cells were transduced with the MSCV-GFP vector or derivatives encoding wild type or mutant $\mathrm{Rb}$ (Figure $1 \mathrm{~A}$ ). In these constructs, $\mathrm{Rb}$ was expressed from the MSCV LTR and GFP from a PGK promoter 3 ' to the RB1 cDNA. The versions of Rb examined included the wild type $\left(\mathrm{Rb}^{\mathrm{WT}}\right)$, the tumor-derived mutants $\mathrm{Rb}^{\Delta 21}$ and $\mathrm{Rb}^{\Delta 22}$ [39], a low penetrance mutant $\left(\mathrm{Rb}^{661 \mathrm{~W}}\right)$ that retains partial tumor suppressor function but lacks the ability to regulate E2F1 [40], and a mutant ( $\left.\mathrm{Rb}^{76 \mathrm{t}}\right)$ with a premature termination codon at amino acid 76 [41].

Viral supernatants were combined with Y79 cells, and infection monitored by flow cytometry. GFP+ cells were first detected $\sim 30 \mathrm{~h}$ after infection, and peaked at $44 \mathrm{~h}$, typically in $10-20 \%$ of cells. At three days after infection, western blotting indicated that similar levels of $\mathrm{Rb}^{\mathrm{WT}}$ and $\mathrm{Rb}^{\Delta 21}$, and slightly higher levels of $\mathrm{Rb}^{661 \mathrm{~W}}$, were produced (Figure 1B).

\section{Antiproliferative effect of retrovirus-transduced $R \boldsymbol{b}$}

To determine whether restoring $\mathrm{Rb}$ with the MSCV-GFP vector affected Y79 proliferation, the percentage of GFP+ cells was determined at various times after infection and normalized to that at $44 \mathrm{~h}$ (Figure 1C). The proportion of $\mathrm{GFP}+$ cells remained constant in cultures transduced with MSCV-GFP, indicating that transduced and untransduced cells proliferated at similar rates. In contrast, the proportion of GFP+ cells rapidly declined after transduction with MSCV-GFP-Rb ${ }^{\mathrm{WT}}$, suggesting that proliferation of $\mathrm{Rb}$ transduced cells was impaired.

Cultures that were transduced with the low penetrance mutant $\mathrm{Rb}^{661 \mathrm{~W}}$ and the tumor-derived mutants $\mathrm{Rb}^{\Delta 21}$ and $\mathrm{Rb}^{\Delta 22}$ displayed an intermediate decline in GFP+ cells (Figure 1C and data not shown). To determine whether this decline required expression of mutant $\mathrm{Rb}$ protein, 
A.

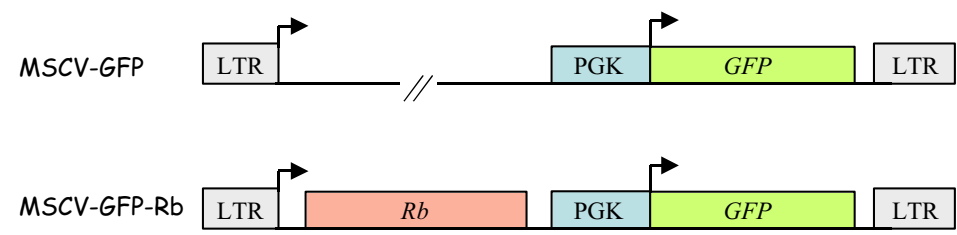

C.

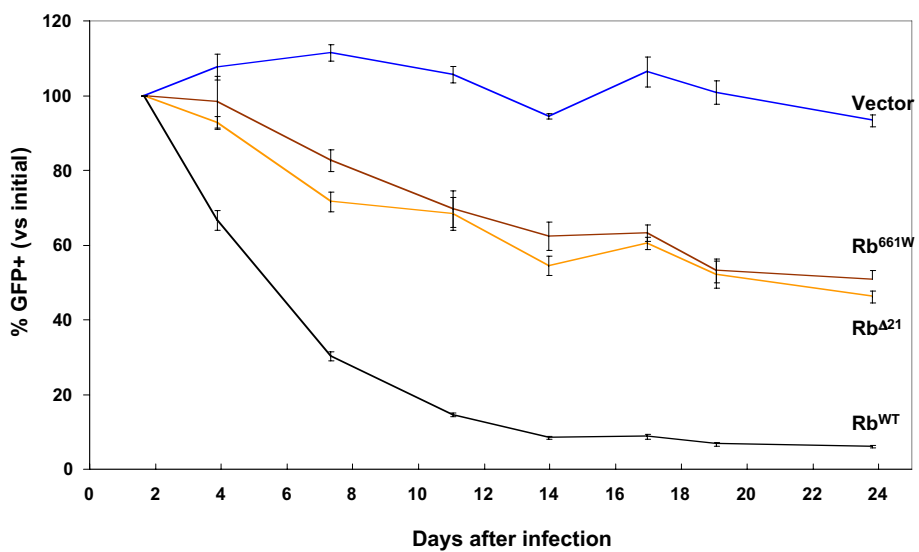

E.

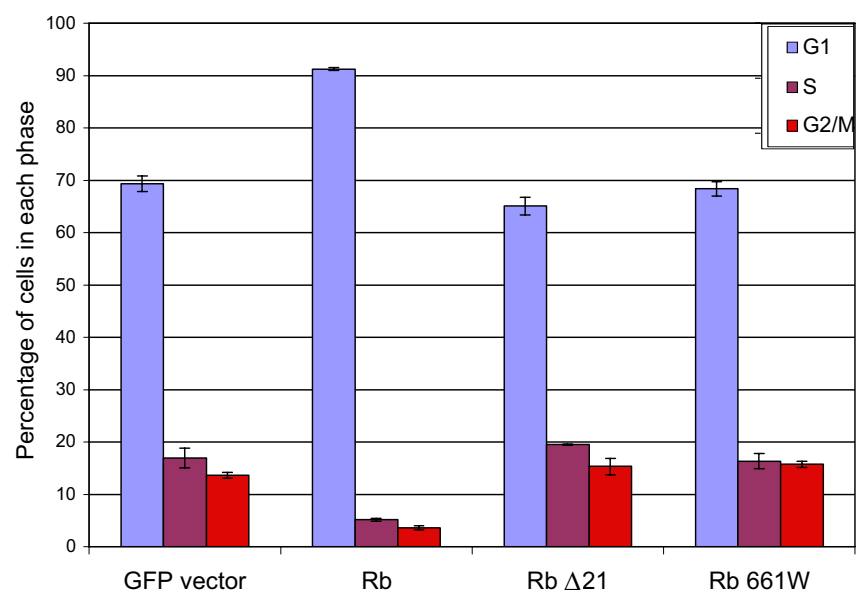

B.

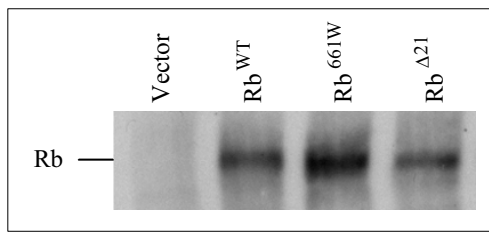

D.

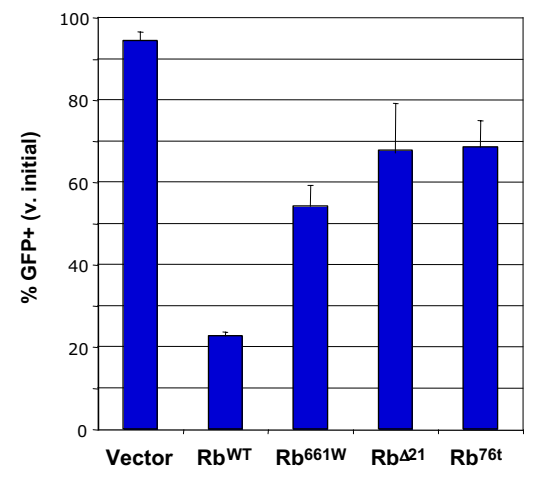

F.

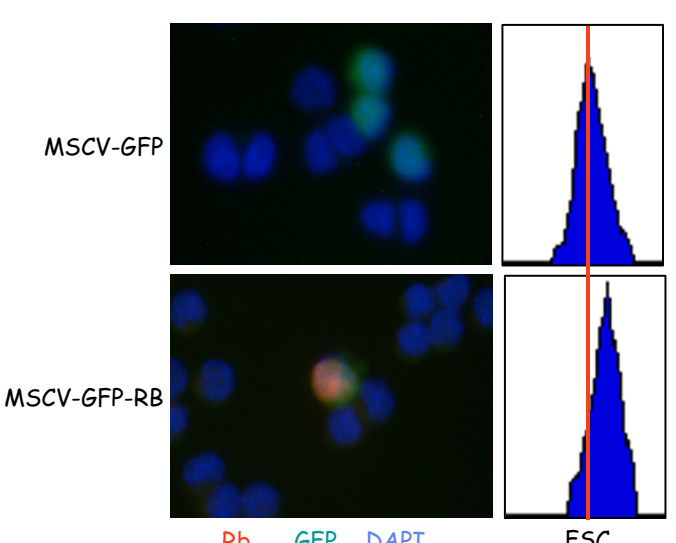

$\mathrm{Rb} \quad$ GFP DAPI

\section{Figure I}

Effect of retroviral Rb transduction on $\mathbf{Y 7 9}$ proliferation. A. Structure of the MSCV-GFP retroviral vector and Rb derivatives. $\mathrm{Rb}$ is expressed from the MSCV LTR, and GFP from a PGK promoter. B. Western analysis of Rb expression 3 days after infection. C, D. Prevalence of GFP+ cells after infection with the indicated vectors, relative to that at $44 \mathrm{~h}$ after infection, displayed as a time course (C) or at day 12 for a separate experiment (D). E. Effect of Rb on cell cycle distribution $84 \mathrm{~h}$ after infection. F. Effect of Rb on cell size. Cells infected with MSCV-GFP or MSCV-GFP-Rb were identified by GFP fluorescence and stained for Rb (left) or measured for forward scatter (FSC) by flow cytometry (right). For C-E, infections were in triplicate, data points represent averages, and error bars indicate standard deviation. 
Y79 cells were transduced with MSCV-GFP-Rb ${ }^{76 t}$, which encodes a truncated and apparently unstable product [41]. As $\mathrm{Rb}^{76 t}$-transduced cultures displayed a similar decline in GFP+ cells (Figure 1D), the decline observed with each mutant was likely due to a cis effect of $R B 1$ sequences that resulted in silencing of GFP expression.

To better define the anti-proliferative effect of $\mathrm{Rb}^{\mathrm{WT}}$, transduced cultures were stained with propidium iodide and the cell cycle profile of GFP+ cells examined. RbWT, but not $\mathrm{Rb}^{661 \mathrm{~W}}$ or $\mathrm{Rb}^{\Delta 21}$, increased the proportion of GFP+ cells in G0/G1 and reduced the proportions in S and G2/ $\mathrm{M}$ (Figure 1E). To our knowledge, this is the first demonstration that restoration of $\mathrm{Rb}$ alters the cell cycle profile of retinoblastoma cells. $\mathrm{Rb} \mathrm{bT}^{\mathrm{WT}}$ but none of the $\mathrm{Rb}$ mutants also increased Y79 cell size, as measured by immunocytochemical staining and the flow cytometry forward scatter parameter (Figure $1 \mathrm{~F}$ and data not shown).

\section{Culture of Rb-transduced cells selects for low $R b$ expression}

In cultures that were transduced with MSCV-GFP-RbWT, the proportion of GFP+ cells declined for two weeks, but then remained constant (Figure 1C), indicating that the remaining GFP+ cells proliferated at the same rate as uninfected cells. To determine whether such cells were selected for decreased $\mathrm{Rb}$, we examined $\mathrm{Rb}$ expression in cell populations that were equivalent to the GFP+ cells in MSCVGFP-Rb transduced cultures, but which expressed puromycin resistance instead of the GFP marker. To do so, Y79 cells were infected with the MSCV-Puro vector or derivatives encoding $\mathrm{Rb}^{\mathrm{WT}}$ or $\mathrm{Rb}^{661 \mathrm{~W}}$, and selected with puromycin. After selection, cells that were transduced with MSCVPuro- $\mathrm{Rb}^{\mathrm{WT}}$, but not those transduced with MSCV-Puro$\mathrm{Rb}^{661 \mathrm{~W}}$, had markedly reduced $\mathrm{Rb}$ protein (Figure $2 \mathrm{~A}, \mathrm{~B}$ ) and RB1 RNA (Figure 2C). Moreover, when the MSCVPuro- $\mathrm{Rb}^{\mathrm{WT}}$-transduced and puromycin-selected cells were re-infected with MSCV-GFP-RbWT, they displayed a rapid decline in the proportion of GFP+ cells, similar to that of the parental Y79 and vector-transduced controls (Figure 2D). This confirmed that $\mathrm{Y} 79$ cells that proliferate after $\mathrm{Rb}$ transduction remain sensitive to $\mathrm{Rb}$, but fail to arrest due to their low $\mathrm{Rb}$ levels.

\section{Restoration of $R b$ using concentrated retroviral and lentiviral vectors}

We next sought to quantitatively restore Rb to Y79 cells, in order to define Rb's biochemical effects. As concentrated MSCV-GFP-Rb preparations infected at most 40\% of Y79 cells, transduced cells were further enriched by FACS, to yield populations that were $\geq 97 \% \mathrm{GFP}+$. As a second approach, we developed a lentiviral vector to express $\mathrm{Rb}$ and GFP, termed Bidirectional-EF1 $\alpha$-GFP (BE-GFP, Figure $3 \mathrm{~A}$ ). A bidirectional promoter was used to tightly link Rb and GFP expression, and thus minimize production of
GFP+ cells that have little or no Rb. Concentrated BE-GFP vector and $\mathrm{Rb}$ derivatives were generally of sufficient titer to transduce $>94 \%$ of $\mathrm{Y} 79$ cells (Figure 3B). This permitted analysis of $\mathrm{Rb}$ effects without further cell isolation.

\section{Antiproliferative effect of lentivirus-transduced $R b^{W T}$ and $\boldsymbol{R b}^{66 \mathrm{IW}}$}

At $60 \mathrm{~h}$ after lentiviral transduction, $\mathrm{Rb}^{\mathrm{WT}}$ induced an accumulation in G0/G1 similar to that induced with retroviral transduction (Figure 3C). Lentiviral transduction of $\mathrm{Rb}^{661 \mathrm{~W}}$ also induced an accumulation in G0/G1, though to a lesser extent than $\mathrm{Rb}^{\mathrm{WT}}$. The ability of $\mathrm{Rb}^{661 \mathrm{~W}}$ to elicit a cell cycle block after lentiviral but not retroviral transduction was most likely due to higher levels of $\mathrm{Rb}^{661 \mathrm{~W}}$ obtained with the EF1 $\alpha$ promoter and a higher multiplicity of infection.

$\mathrm{Rb}^{\mathrm{WT}}$ and $\mathrm{Rb}^{661 \mathrm{~W}}$ were previously found to inhibit osteosarcoma cell proliferation by inducing a post-transcriptional increase in p27 KIP1 $[13,14]$. Similarly, $\mathrm{Rb}^{\mathrm{WT}}$ and $\mathrm{Rb}^{661 \mathrm{~W}}$ induced $\mathrm{p} 27$ in $\mathrm{Y} 79$ cells, at levels that were in proportion to $\mathrm{Rb}$ protein expression (Figure 3D). To determine whether p27 might mediate the Rb-induced proliferative arrest, we compared the effects of ectopic $\mathrm{Rb}$ and ectopic p27, using the same lentiviral vector to express each protein. Lentiviral p27 transduction resulted in higher p27 levels, but caused less of an accumulation in G0/G1, as compared to lentiviral Rb (Figure 4). This implies that p27 does not fully mediate the Rb-induced G0/G1 arrest.

\section{Effect of $R \boldsymbol{b}$ on gene expression}

$\mathrm{Rb}$ is thought to inhibit proliferation, in part, by repressing E2F-regulated cell cycle genes and promoting expression of cell type-specific differentiation genes. Thus, we performed a microarray analysis to assess Rb's effects on E2F-responsive genes and to identify additional Rb-regulated genes in retinoblastoma cells. RNA was obtained from FACS-purified GFP+ Y79 cells at $60 \mathrm{~h}$ after transduction with MSCV-GFP or MSCV-GFP-Rb ${ }^{W T}$, and analyzed by Affymetrix GeneChip. Among well-described E2Fresponsive genes, CDC2,CDK2, cyclin E2, polo-like kinase (PLK), and p107 (RBL1) were scored as more than 2-fold repressed, whereas others had comparatively little change (Table 1). Of these, cyclin E2 and p107 are among the small subset of E2F-responsive genes that typically require $\mathrm{Rb}$ for normal regulation $[11,42-44]$. Rb had little effect on cyclin $E 1$, despite that $\mathrm{Rb}$ is required for normal cyclin E1 regulation in other cell types $[44,45]$.

We further examined the gene expression effects of $\mathrm{Rb}$ and $\mathrm{Rb}$ mutants at $60 \mathrm{~h}$ after transduction with the BE-GFP lentiviral vector. In quantitative reverse transcription (qRT)-PCR analyses, BE-GFP-Rb ${ }^{\mathrm{WT}}$ diminished $c y c l i n$ E2 expression by $\sim 90 \%$ and decreased cyclin $E 1$ by $~ 50 \%$, 
A.
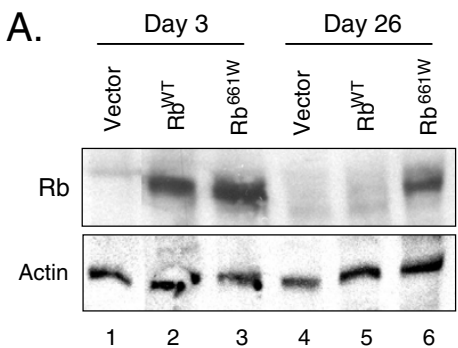

B.
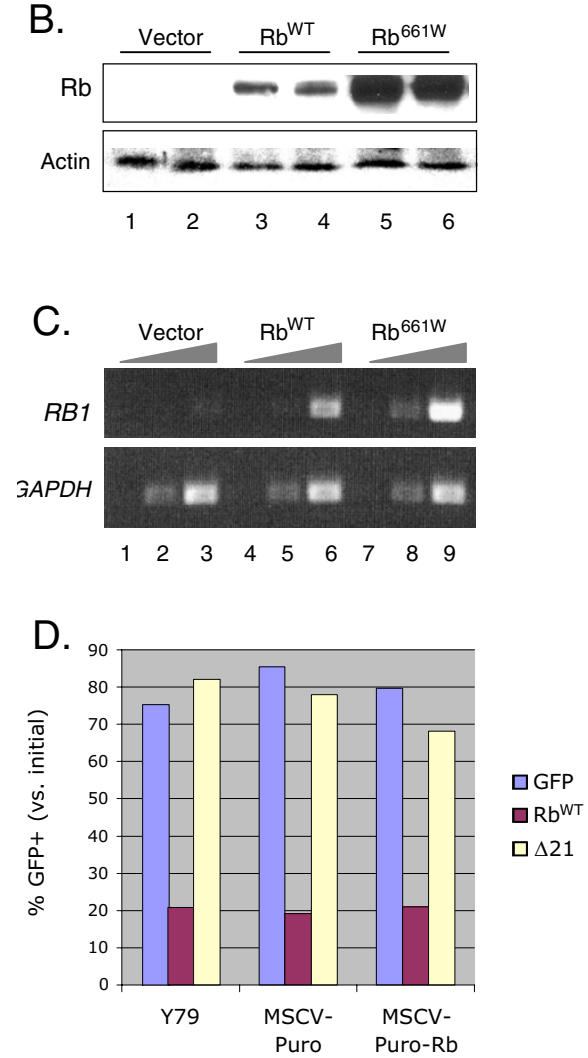

Figure 2

Long-term culture of Rb-transduced cells selects for low Rb expression. A. Rb expression in Y79 cells 3 days after transduction with MSCV-GFP and Rb derivatives (lanes I-3), or in puromycin resistant $Y 79$ cells 26 days after transduction with MSCV-Puro and Rb derivatives (lanes 4-6). Lysates from infected cultures were combined with mockinfected cell lysates to normalize the proportion of GFP+ cells. B. Rb expression after transduction with the indicated MSCV-Puro viruses and puromycin selection, at 19 days (lanes I, 3, and 5) and 26 days (lanes 2, 4, and 6) after infection. For $\mathbf{A}$ and $\mathbf{B}$, actin expression is displayed as a loading control. C. RT-PCR analysis of RBI and GAPDH mRNA in puromycin resistant cells after infection with the indicated viruses, with PCR for 22, 26, and 30 cycles. D. Prevalence of GFP+ cells at 12 days relative to that at $44 \mathrm{~h}$ after infection of Y79 cells, or after infection of puromycin-selected Y79 derivatives that were earlier infected with MSCV-Puro or MSCVPuro-Rb. whereas $\mathrm{Rb}^{\Delta 21}$ and $\mathrm{Rb}^{76 t}$ derivatives had little or no effect (Figure $5 \mathrm{~A}$ ). The greater effect of $\mathrm{Rb}^{\mathrm{WT}}$ on $c y c l i n \mathrm{E}$ expression after lentiviral transduction and qRT-PCR analysis, compared to retroviral transduction and microarray analysis, may be due to the higher $\mathrm{Rb}$ levels expressed from the $\mathrm{BE}-\mathrm{GFP}$ vector as well as methodological differences. BEGFP-Rb ${ }^{661 \mathrm{~W}}$ also down regulated cyclin E1 and cyclin E2 by $\sim 50 \%$. The $\mathrm{Rb}^{\mathrm{WT}}$ and $\mathrm{Rb}^{661 \mathrm{~W}}$ effects appeared to be specific, as Rb did not repress the control gene, HSP70A1B.

We next sought to identify additional Rb-regulated genes. One of the most strongly down-regulated genes in the microarray analysis was Brn-2 (POU3F2), with a 20-fold reduction in signal (Table 1). This effect was confirmed with qRT-PCR analysis of lentivirus-transduced cells, in which $\mathrm{Rb}^{\mathrm{WT}}$ repressed $\mathrm{Brn}-2$ by $~ 90 \%$ (Figure $5 \mathrm{~A}$ ). Moreover, $\mathrm{Rb}^{661 \mathrm{~W}}$ down-regulated $B r n-2$ by $50 \%$, while $\mathrm{Rb}^{\Delta 21}$ and $\mathrm{Rb}^{76 t}$ had no effect. $\mathrm{Rb}$ 's regulation of $\mathrm{Brn}-2$ was of interest because $\mathrm{Brn}-2$ functions as an oncogene in melanoma cells and is implicated in the control of Chx10 and other genes that are expressed in RPCs $[46,47]$. To determine whether this effect indirectly resulted from Rbinduced cell cycle arrest or p27 expression, we examined Brn-2 expression after p27 transduction. Ectopic p27 increased the proportion of cells in G0/G1 (Figure 4B), but induced rather than diminished $\mathrm{Brn}$-2 expression (Figure $5 \mathrm{~B})$. This implies that $\mathrm{Rb}$ does not repress $\mathrm{Brn}-2$ through its induction of $\mathrm{p} 27$, nor by inducing a G0/G1 arrest.

In summary, $\mathrm{Rb}$ not only down regulated E2F-responsive genes, which are thought to have general, cell type-independent functions. $\mathrm{Rb}$ also down regulated $\mathrm{Brn}-2$, which is particularly important to the regulation of gene expression in RPCs.

\section{Discussion}

Retinoblastoma has long served as a paradigm for cancers that develop due to the loss of a tumor suppressor protein [48]. However, despite that the $\mathrm{Rb}$ tumor suppressor was identified 20 years ago, the means by which Rb suppresses this tumor have not been established. In the current study, we examined the effect of restoring $\mathrm{Rb}$ to retinoblastoma cells. Our rationale was that $\mathrm{Rb}$ might perform functions in retinoblastoma cells that it does not display in other available cell types, and which may relate to Rb's role in the retinoblastoma cell of origin. As the retinoblastoma cell of origin has not been identified, and cell types that are candidates for the cell of origin are not easily manipulated, retinoblastoma cells may serve as the best available setting in which to detect $\mathrm{Rb}$ functions that specifically relate to the suppression of this tumor.

Earlier attempts to define Rb's effects in retinoblastoma cells may have been hampered by an inability to effi- 
A.

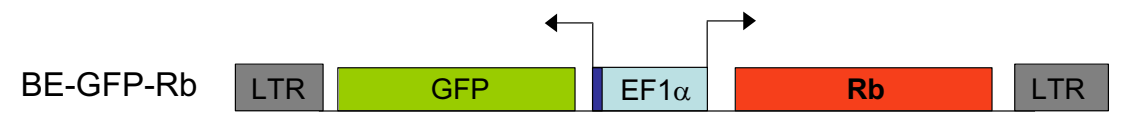

C.

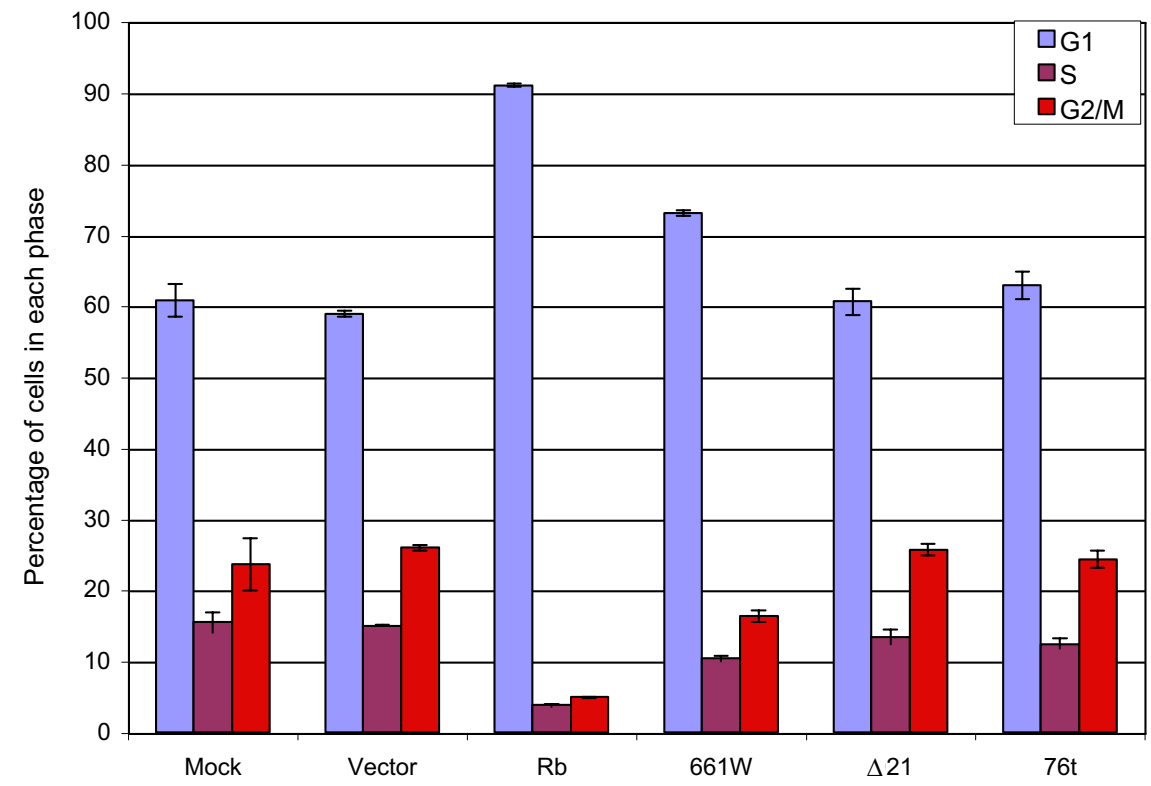

D.

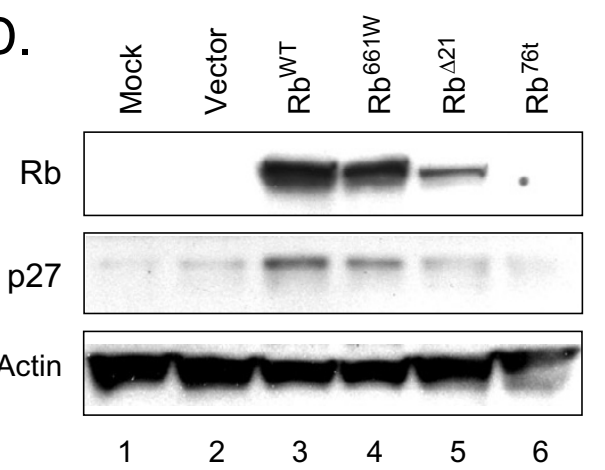

B.
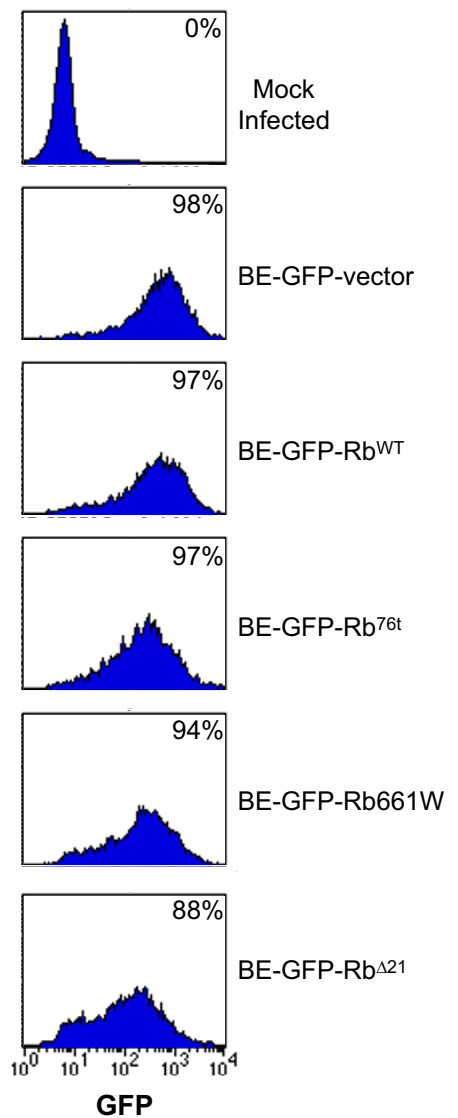

GFP

\section{Figure 3}

Lentiviral transduction of Y79 with BE-GFP-Rb. A. Structure of BE-GFP-RbWT. Rb and GFP are expressed from a bidirectional promoter consisting of $E F I \alpha$ enhancer + promoter (light blue) and a minimal CMV promoter (dark blue) that requires a heterologous enhancer for activity [56]. B. Flow cytometric analysis of GFP expression in transduced cultures at $56 \mathrm{~h}$ after infection. Numbers indicate the percent GFP+ cells. C. Y79 cell cycle profiles $60 \mathrm{~h}$ after mock infection or transduction with the indicated BE-GFP viruses. D. Western analysis of Rb, p27, and $\alpha$-actin $60 \mathrm{~h}$ after mock infection (lane I) or infection with the indicated BE-GFP viruses (lanes 2-6). 
A.

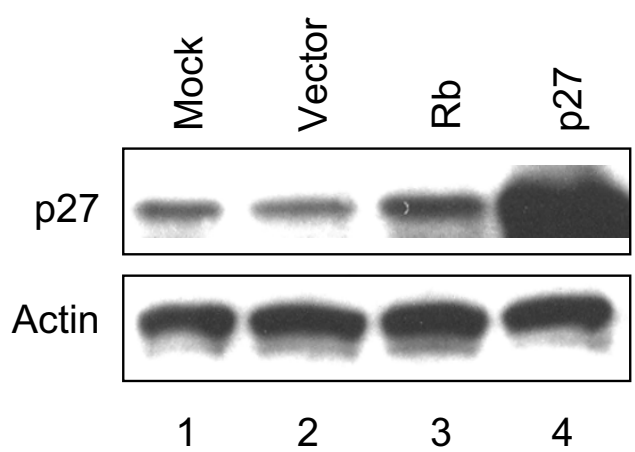

B.

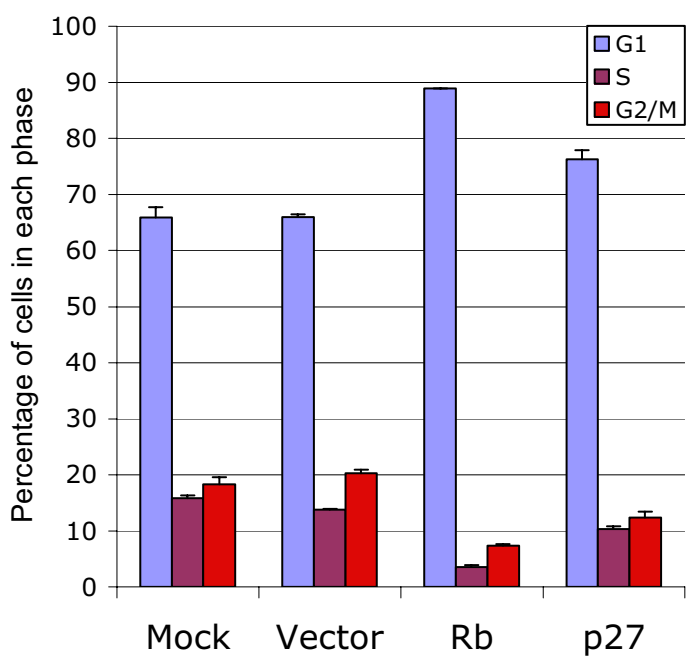

\section{Figure 4}

Comparison of Rb and p27 cell cycle effect. A. Y79 cells were mock infected (lane I) or infected with BE-GFP, BE-GFP-Rb, or BE-GFP-p27 (lanes 2-4); and examined by western blotting for $\mathrm{p} 27$ expression, and for actin expression as a loading control. B. Infected cells were stained with propidium iodide and examined for cell cycle position.

ciently express $\mathrm{Rb}$ and thus examine its acute effects. The current study surmounted this obstacle by marking the $\mathrm{Rb}$ expression vectors with GFP. This approach revealed that $\mathrm{Rb}$ inhibited proliferation, induced a G0/G1 arrest, and increased cell size, similar to Rb's effects in other cell types. Moreover, the studies showed that Rb's anti-proliferative effect was masked when analyzed several weeks after infection, due to the outgrowth of cells that had low $\mathrm{Rb}$ levels. This implies that prior studies that failed to demonstrate an antiproliferative effect of $\mathrm{Rb}$ after a selection period may have analyzed cells that had ineffective levels or $\mathrm{Rb}$ expression. The firm demonstration that $\mathrm{Rb}$ inhibits retinoblastoma proliferation validates efforts to restore $\mathrm{Rb}$ function as a therapeutic approach [49]. How- ever, our results also revealed that a threshold level of $\mathrm{Rb}$ was required to inhibit Y79 proliferation in vitro. Whether a similar $\mathrm{Rb}$ level is needed to inhibit growth of retinoblastoma tumors in vivo remains to be established.

The Rb-induced G0/G1 arrest was associated with increased expression of p27 and decreased expression of E2F-responsive genes, as previously observed in other cell types. In osteosarcoma cells, the induction of p27 preceded the decline in proteins encoded by E2F-responsive genes, and was needed for $\mathrm{Rb}$ to rapidly induce a cell cycle block [14]. To date, it has not been possible to determine whether the up-regulation of p27 is required for $\mathrm{Rb}$ to arrest Y79 cells, as p27 knockdown did not preclude the induction of p27 by Rb (data not shown). However, our finding that $\mathrm{Rb}$ was more effective than $\mathrm{p} 27$ in inducing a G0/G1 arrest suggests that $\mathrm{Rb}$ inhibits Y79 proliferation at least in part through a p27-independent process, such as by repressing cyclin E2 and other E2F-responsive genes. Notably, the low penetrance mutant $\mathrm{Rb}^{661 \mathrm{~W}}$ also induced a G0/G1 block, p27 expression, and down-regulation of cyclin $E$, albeit to a lesser extent than $\mathrm{Rb}^{\mathrm{WT}}$. This is consistent with the ability of $\mathrm{Rb}^{661 \mathrm{~W}}$ to induce a proliferative arrest via p27 in osteosarcoma cells [14], and with evidence that $\mathrm{Rb}^{661 \mathrm{~W}}$ may regulate $\mathrm{E} 2 \mathrm{~F}$-responsive genes through an interaction with E2F2 [50].

In addition to Rb's effect on E2F-regulated genes, $\mathrm{Rb}$ strongly repressed $B r n-2$. This effect is notable in light of evidence that $\mathrm{Brn}$-2 is highly expressed small cell lung cancers [51], which like retinoblastomas generally lack $\mathrm{Rb}$ [39], and in light of evidence that Brn-2 functions as an oncogene in melanoma cells $[46,52]$. Thus, the finding that $\mathrm{Rb}$ represses $\mathrm{Brn}-2$ raises the possibility that deregulation of Brn-2 contributes to retinoblastoma tumorigenesis.

During retinal development, Brn-2 is expressed in intermediate and late RPCs as well as in certain post-mitotic cells [47]. Brn-2 may have a widespread transcriptional role in RPCs, as it binds the promoters of the characteristic RPC genes, Chx10 and Nestin, and may bind related promoter sites in Cyclin D1 and Pax6 [47]. In cortical development, Brn-2 is similarly expressed in late progenitors, and is required in combination with Brn-1 for late progenitor cell proliferation [53]. These findings suggest that Brn2 may promote the expression of genes that maintain late progenitor cell proliferation, and that deregulation of $\mathrm{Brn}$ 2 in response to $\mathrm{Rb}$ loss may elicit aberrant expression of such genes, increased proliferation, and retinoblastoma tumorigenesis. Alternatively, as $\mathrm{Rb}$ is also expressed in post-mitotic retinal cells [29], Rb-mediated repression of Brn-2 may contribute to the suppression of retinoblastoma in post-mitotic retinal precursors. 
Table I: Gene expression effects of retroviral Rb transduction

\begin{tabular}{|c|c|c|}
\hline Gene & Probe Set Accession \# & Fold Change \\
\hline \multicolumn{3}{|l|}{ Controls } \\
\hline \multirow[t]{3}{*}{$\overline{G A P D H}$} & M33197_M_at & 0.92 \\
\hline & M33197_3_at & 0.91 \\
\hline & M33197_5_at & 0.82 \\
\hline$\beta$-actin & 200801_x_at & 1.07 \\
\hline \multicolumn{3}{|l|}{ E2F-responsive } \\
\hline \multirow[t]{4}{*}{$C D C 2$} & 203214_x_at & 0.53 \\
\hline & 210559_s_at & 0.63 \\
\hline & 203213_at & 0.70 \\
\hline & 231534_at & $0.43^{*}$ \\
\hline \multirow[t]{2}{*}{$C D C 25 A$} & 204695_at & 0.60 \\
\hline & 1555772_a_at & 0.76 \\
\hline$C D C 25 B$ & 201853_s_at & 0.93 \\
\hline$C D C 25 C$ & 205167_s_at & 0.89 \\
\hline$C D K 2$ & 204252_at & $0.38^{*}$ \\
\hline Cyclin A2 & 203418_at & 0.61 \\
\hline \multirow[t]{2}{*}{ Cyclin BI } & 214710_s_at & 0.74 \\
\hline & 228729_at & 0.76 \\
\hline Cyclin B2 & 202705_at & 0.76 \\
\hline Cyclin EI & 213523_at & 0.92 \\
\hline \multirow[t]{2}{*}{ Cyclin E2 } & 211814_s_at & $0.37^{*}$ \\
\hline & 205034_at & 0.61 \\
\hline \multirow[t]{2}{*}{$\mathrm{E} 2 \mathrm{FI}$} & 204947_at & 0.92 \\
\hline & 2028_s_at & 0.67 \\
\hline E2F2 & 22836I_at & 0.56 \\
\hline \multirow{2}{*}{$E 2 F 3$} & 203692_s_at & 1.31 \\
\hline & 203693_s_at & 1.02 \\
\hline \multirow[t]{2}{*}{ EMII (FBXO5) } & 218875_s_at & 0.66 \\
\hline & 234863_x_at & 0.55 \\
\hline Geminin & 218350_s_at & 0.63 \\
\hline HPRT & 202854_at & 0.65 \\
\hline$N-m y c$ & 209757_s_at & 1.06 \\
\hline PCNA & 201202_at & 0.90 \\
\hline \multirow{2}{*}{ PLK } & 214372_x_at & 0.80 \\
\hline & 202240_at & $0.42^{*}$ \\
\hline RbLI (p/07) & 1555004_a_at & $0.44^{*}$ \\
\hline \multirow[t]{2}{*}{ Ribonuc. Reductase MI } & 201477_s_at & 0.65 \\
\hline & 201476_s_at & 0.50 \\
\hline Ribonuc. Reductase M2 & 209773_s_at & 0.74 \\
\hline \multirow[t]{2}{*}{$S K P 2$} & 210567_s_at & 1.16 \\
\hline & 203626_s_at & 0.77 \\
\hline \multirow[t]{2}{*}{ Thymidlyate Synthase } & 202589_at & 0.74 \\
\hline & 1554696_s_at & 0.57 \\
\hline \multirow[t]{3}{*}{ Thymidine Kinase } & 243103_at & 0.98 \\
\hline & I554408_a_at & 0.82 \\
\hline & 202338_at & 0.59 \\
\hline \multicolumn{3}{|l|}{ Novel } \\
\hline Brn-2 (POU3F2) & 207084_at & $0.05^{* *}$ \\
\hline
\end{tabular}

Affymetrix U133 Plus 2.0 microarrays were hybridized with probes from vector- and Rb-transduced cells and analyzed with Affymetrix Microarray Suite software. The indicated probe sets were flagged as "Present" in vector transduced samples, and showed the indicated fold change in signal for $\mathrm{Rb}$-transduced versus vector-transduced samples. Asterisks indicate probe sets with fold change less than 0.5 . The double asterisk indicates one of the most strongly down-regulated genes in the microarray analysis.

\section{Conclusion}

$\mathrm{Rb}$ was expressed in Y79 cells using novel retroviral and lentiviral vectors. $\mathrm{Rb}$ induced a G0/G1 arrest, expression of $\mathrm{p} 27^{\mathrm{KIP} 1}$, and repression of E2F-responsive genes such as cyclin E1 and cyclin E2, similar to Rb's effects in other cell types. In addition, $\mathrm{Rb}$ decreased expression of $\mathrm{Brn}-2$, 
A.

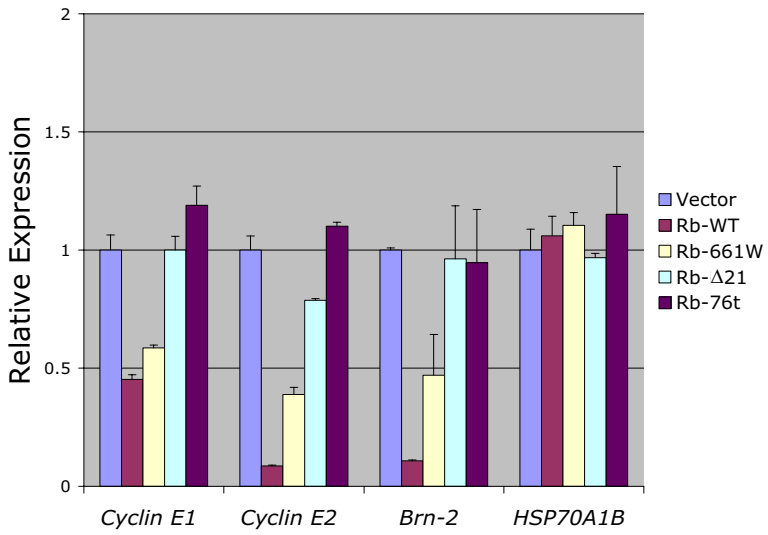

B.

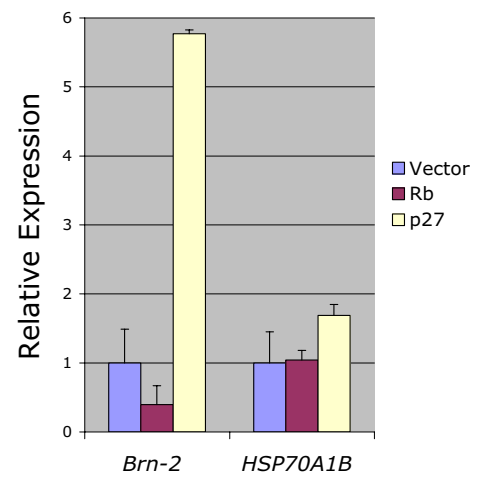

Figure 5

Gene expression effects of Rb and p27. cDNA was prepared from cells at $60 \mathrm{~h}$ after infection with the BE-GFP vector and $\mathbf{A}$ ) the indicated $\mathrm{Rb}$ derivatives, or $\mathbf{B}$ ) either $\mathrm{Rb} W \mathrm{WT}$ or p27 derivatives. The CDNA was subjected to GRT-PCR for the indicated genes. Expression levels were normalized to $\beta$-actin and are displayed relative to that of vector-transduced samples. Values indicate averages of duplicate analyses and error bars indicate standard deviation.

which selectively regulates gene expression in RPCs and related cells. Thus, in addition to Rb's cell type-independent effects, $\mathrm{Rb}$ regulates genes that control transcription in the developing retina.

\section{Methods}

\section{DNA constructs}

MSCV-GFP was constructed by replacing the HindIII-ClaI fragment of MSCV-Puro (Clontech) with a HindIII-NotI fragment from pEGFP-N2 (Clontech). To produce MSCVGFP derivatives, BamHI-StuI fragments from pSVEhRBWT, pSVE-hRB ${ }^{\Delta 22}$ [54], pSVE-hRB ${ }^{661 W}$ [DC unpublished data, 40], and pSVE-Rb ${ }^{76 t}[41]$ were inserted to the BglII-HpaI sites of MSCV-GFP. Similarly, MSCV-Puro$\mathrm{Rb}^{\mathrm{WT}}$ was produced by inserting the pSVE-hRBWT BamHI-
StuI fragment in the MSCV-Puro BglII-HpaI site. MSCVGFP-Rb ${ }^{\Delta 21}$ was produced by replacing an MluI-MfeI fragment of MSCV-GFP-RbWT with the corresponding sequence from $\mathrm{pGST}-\mathrm{Rb}^{\Delta 21}[55]$.

BE-GFP was produced by replacing the EcoRV-Sall fragment of MA1, containing a PGK-TrkA cassette [56], with the polylinker sequence 5'-GGGGCTAGCTCTAGAACGCGTCGTACGACTCGAGTGTTTAAAC-3', and inserting an EF1 1 promoter fragment between the polylinker NheI-XbaI sites. $\mathrm{Rb}^{\mathrm{WT}}, \mathrm{Rb}^{661 \mathrm{~W}}, \mathrm{Rb}^{\Delta 21}$, and $\mathrm{Rb}^{76 \mathrm{t}}$ cDNAs were transferred as BssHII-BsrGI fragments from MSCV-GFP to the BE-GFP MluI-BsiWI sites. p27 ${ }^{\mathrm{KIP} 1} \mathrm{cDNA}$ was transferred as a KpnI-XbaI fragment from $\mathrm{CDNA}_{3}$-p27 (kindly provided by A. Koff) to the corresponding BE-GFP sites.

Cell growth, virus production, infection, and Y79 sublines Y79 cells were obtained from the ATCC and cultured in RPMI 1640, 10\% fetal calf serum (FCS), penicillin, streptomycin, and L-glutamine, in a humidified $5 \% \mathrm{CO}_{2}$ incubator. Retroviral supernatants used for direct infections were made by $\mathrm{CaPO}_{4}$-mediated co-transfection of Bing producer cells with the indicated MSCV-GFP constructs and pCL-Ampho [57]. Concentrated retrovirus was produced by $\mathrm{CaPO}_{4}$-mediated co-transfection of GP2 cells (Clontech) with MSCV-GFP constructs and pVSVg [58]. Lentivirus was produced using Lipofectamine 2000 (InVitrogen) to co-transfect $293 \mathrm{~T}$ cells with the viral vector, pVSVg, and p 48.91 DNAs [59]. Cell supernatants were passed through $0.45 \mu \mathrm{m}$ cellulose acetate filters $48 \mathrm{~h}$ after transfection. Virus was concentrated by centrifugation at $25,000 \mathrm{rpm}$ for $90 \mathrm{~min}$ in a SW28 rotor, and suspended in $50 \mathrm{mM}$ Tris, pH 7.8, $130 \mathrm{mM} \mathrm{NaCl}$, and $1 \mathrm{mM}$ EDTA. For infections, Y79 cells were plated at $2 \times 10^{6}$ cells per ml and combined with an equal volume of producer cell supernatants, or with up to 0.5 volume of concentrated virus, at 6 $\mu \mathrm{g} / \mathrm{ml}$ polybrene. As MSCV-GFP titers were 10 -fold higher than for Rb derivatives, MSCV-GFP supernatants were diluted 10 -fold prior to infection.

Cells transduced with MSCV-Puro or Rb derivatives were selected with $1.5 \mu \mathrm{g} / \mathrm{ml}$ puromycin for 11 days, and reinfected with MSCV-GFP and Rb derivatives 20 days after the initial infection.

\section{Analysis of infected cells}

GFP expression and forward scatter were determined using a Becton-Dickenson FACSCaliber and CellQuest Software. Cell cycle positions of retrovirus-transduced cells were determined by fixing in $0.75 \%$ paraformaldehyde (PFA) for $30 \mathrm{~min}$ at $22^{\circ} \mathrm{C}$, washing in PBS $+3 \%$ FCS, fixing in $70 \%$ ethanol at $-20^{\circ} \mathrm{C}$, staining in $0.05 \mathrm{mg} / \mathrm{ml}$ propidium iodide, $0.6 \%$ Nonidet-P40 in PBS, and $1 \mathrm{mg} /$ ml RNAse A, and gating on diploid GFP+ cells. Cell cycle 
positions of lentivirus-transduced cells were determined as above but without PFA fixation or GFP gating.

For immunofluorescent detection of $\mathrm{Rb}, \mathrm{Y} 79$ cells were attached to poly-L-lysine coated slides, fixed in 4\% PFA for $10 \mathrm{~min}$ and stained with anti-Rb antibody G3-245 (1:200, Becton-Dickenson) and Cy3-conjugated donkey anti-mouse. For immunoblotting, lysates were separated and immunoblotted to Hybond-P and probed using ECLAdvance (Amersham), with mouse anti-Rb G3-245 $(1: 1,200)$, rabbit anti-p27 (1:150, SantaCruz sc-528), and rabbit anti- $\alpha$-actin $(1: 1,000$, Sigma A2066). To compare $\mathrm{Rb}$ expression after retroviral infection, infected cell lysates were combined with mock-infected cell lysates to normalize for the proportion of GFP+ cells.

RB1 cDNA expressed following retroviral transduction was detected by RT-PCR with forward primer 5'-GCTTGAGTTTGAAGAAACAGAAGAACC and reverse primer 5'CTTTAGCTAATAAAAATGTGATCCAAGAAACTT, and with a GAPDH control.

\section{Gene expression analysis}

RNA was prepared $60 \mathrm{~h}$ after lentivirus infection or after retrovirus infection followed by FACS enrichment to $>97 \%$ GFP+ cells. In the latter case, cells were suspended in Buffer RLT (Qiagen) within 10 min after sorting. RNA was prepared using RNeasy (Qiagen) including on-column DNAse digestion, and RNA quality confirmed by Agilent BioAnalyzer. For microarray analysis, $10 \mathrm{ng}$ of each RNA was used to prepare probes with the Ovation Biotin Amplification System (Novogen), and probing Affymetrix U133 Plus 2.0 GeneChip. For real-time quantitative PCR (RT-qPCR), oligo dT-primed cDNA was prepared from $750 \mathrm{ng}$ RNA and ImProm-II reverse transcriptase (Promega), and cDNA transcribed from $5 \mathrm{ng}$ of RNA subjected to RT-qPCR using iTaq SYBR Green Supermix (Bio-Rad), and normalized to $\beta$-actin RNA measured by Taqman (Applied Biosystems). PCR primers were for cyclin E1 (forward 5'-CGTGCGTTTGCTTTTACAGA, reverse 5'-AGCACCTTCCATAGCAGCAT); cyclin E2 (forward 5'-CCTCCATTGTGAGATAAGGACA, reverse 5'-GCCTATGTACAGCAAGTTTTCA); Brn-2 (forward 5'CAGAGAGATGGCAAGCACTG, reverse 5'-TCAGGAAGCTGCATTTTGTG); and HSP70A1B (forward 5'CCGAGAAGGACGAGTTTGAG, reverse 5'-GCAGCAAAGTCCTTGAGTCC).

\section{Competing interests}

The author(s) declare that they have no competing interests.

\section{Authors' contributions}

DC conceived the study, participated in its design, constructed lentiviral vectors, analyzed the effects of retroviral and lentiviral $\mathrm{Rb}$ transduction, and drafted the manuscript. ROF designed, constructed, and analyzed transduction by retroviral $\mathrm{Rb}$ vectors. DHA and TCL participated in the conception and design of the study. All authors read and approved the final manuscript.

\section{Acknowledgements}

We thank Drs. L. Naldini, P. Hinds, W. Kaelin, F. Kaye, and A. Koff for DNA constructs, and Dr. Jenny Xiang of Weill Medical College Microarray Core Facility for assistance with microarray analysis. This work was supported by grants from the C.V. Starr Foundation, the Fred Gluck Foundation,

Research to Prevent Blindness, and the New York Community Trust.

\section{References}

I. DiCiommo D, Gallie BL, Bremner R: Retinoblastoma: the disease, gene and protein provide critical leads to understand cancer. Semin Cancer Biol 2000, 10:255-269.

2. Abramson $\mathrm{DH}$, Schefler AC: Update on retinoblastoma. Retina 2004, 24:828-848.

3. Abramson DH, Gombos DS: The topography of bilateral retinoblastoma lesions. Retina 1996, 16:232-239.

4. Abramson DH: Second nonocular cancers in retinoblastoma: a unified hypothesis. The Franceschetti Lecture. Ophthalmic Genet 1999, 20:193-204.

5. Fugaro MN, Kiupel M, Montiani-Ferreira F, Hawkins JF, Janovitz EB: Retinoblastoma in the eye of a llama (Llama glama). Vet Ophthalmol 2005, 8:287-290.

6. Syed NA, Nork TM, Poulsen GL, Riis RC, George C, Albert DM: Retinoblastoma in a dog. Arch Ophthalmol 1997, I I 5:758-763.

7. Robanus-Maandag E, Dekker M, van der Valk M, Carrozza ML, Jeanny JC, Dannenberg JH, Berns A, te Riele H: plo7 is a suppressor of retinoblastoma development in pRb-deficient mice. Genes Dev 1998, 12:1599-1609.

8. MacPherson D, Sage J, Kim T, Ho D, McLaughlin ME, Jacks T: Cell type-specific effects of $R \mathbf{b}$ deletion in the murine retina. Genes Dev 2004, 18:1681-1694.

9. Chen D, Livne-bar I, Vanderluit JL, Slack RS, Agochiya M, Bremner R: Cell-specific effects of $R B$ or $R B / p 107$ loss on retinal development implicate an intrinsically death-resistant cell-of-origin in retinoblastoma. Cancer Cell 2004, 5:539-55I.

10. Zhang J, Schweers B, Dyer MA: The First Knockout Mouse Model of Retinoblastoma. Cell Cycle 2004, 3:952-959.

II. Cobrinik D: Pocket proteins and cell cycle control. Oncogene 2005, 24:2796-2809.

12. Qin XQ, Livingston DM, Ewen M, Sellers WR, Arany Z, Kaelin WG Jr.: The transcription factor E2F-I is a downstream target of RB action. Mol Cell Biol 1995, 15:742-755.

13. Alexander K, Hinds PW: Requirement for p27(KIPI) in retinoblastoma protein-mediated senescence. Mol Cell Biol 200I, 21:3616-3631.

14. Ji P, Jiang H, Rekhtman K, Bloom J, Ichetovkin M, Pagano M, Zhu L: An Rb-Skp2-p27 Pathway Mediates Acute Cell Cycle Inhibition by $\mathbf{R b}$ and Is Retained in a Partial-Penetrance Rb Mutant. Mol Cell 2004, 16:47-58.

15. Sellers WR, Novitch BG, Miyake S, Heith A, Otterson GA, Kaye FJ, Lassar AB, Kaelin WG: Stable binding to E2F is not required for the retinoblastoma protein to activate transcription, promote differentiation, and suppress tumor cell growth. Genes Dev 1998, I 2:95-106.

16. Maehara K, Yamakoshi K, Ohtani N, Kubo Y, Takahashi A, Arase S, Jones N, Hara E: Reduction of total E2F/DP activity induces senescence-like cell cycle arrest in cancer cells lacking functional pRB and p53. J Cell Biol 2005, 168:553-560.

17. Xu HJ, Zhou Y, Ji W, Perng GS, Kruzelock R, Kong CT, Bast RC, Mills $\mathrm{GB}, \mathrm{Li}$ J, Hu SX: Reexpression of the retinoblastoma protein in tumor cells induces senescence and telomerase inhibition. Oncogene 1997, 15:2589-2596.

18. Gagrica S, Hauser S, Kolfschoten I, Osterloh L, Agami R, Gaubatz S: Inhibition of oncogenic transformation by mammalian Lin-9, a pRB-associated protein. Embo J 2004, 23:4627-4638.

19. Gutierrez GM, Kong E, Hinds PW: Master or slave: the complex relationship of RBP2 and pRb. Cancer Cell 2005, 7:50I-502. 
20. Takahashi C, Contreras B, Bronson RT, Loda M, Ewen ME: Genetic interaction between Rb and K-ras in the control of differentiation and tumor suppression. Mol Cell Biol 2004, 24:10406-104I5.

21. Thomas DM, Carty SA, Piscopo DM, Lee J, Wang W, Forrester WC, Hinds PW: The retinoblastoma protein acts as a transcriptional coactivator required for osteogenic differentiation. Mol Cell 200I, 8:303-3I6.

22. Scime A, Grenier G, Huh MS, Gillespie MA, Bevilacqua L, Harper ME, Rudnicki MA: Rb and plo7 regulate preadipocyte differentiation into white versus brown fat through repression of PGCI alpha. Cell Metab 2005, 2:283-295.

23. Chen PL, Riley DJ, Chen Y, Lee WH: Retinoblastoma protein positively regulates terminal adipocyte differentiation through direct interaction with C/EBPs. Genes Dev 1996, 10:2794-2804.

24. Hansen JB, Jorgensen C, Petersen RK, Hallenborg P, De Matteis R, Boye HA, Petrovic N, Enerback S, Nedergaard J, Cinti S, te Riele H, Kristiansen K: Retinoblastoma protein functions as a molecular switch determining white versus brown adipocyte differentiation. Proc Natl Acad Sci U S A 2004, I 0 I:4 | | 2-4 I I7.

25. Miccadei S, Provenzano C, Mojzisek M, Natali PG, Civitareale D: Retinoblastoma protein acts as Pax 8 transcriptional coactivator. Oncogene 2005, 24:6993-700I.

26. Carreira S, Goodall J, Aksan I, La Rocca SA, Galibert MD, Denat L, Larue L, Goding CR: Mitf cooperates with RbI and activates p2 I Cip I expression to regulate cell cycle progression. Nature 2005, 433:764-769.

27. Kyritsis AP, Tsokos M, Triche TJ, Chader GJ: Retinoblastoma--origin from a primitive neuroectodermal cell? Nature 1984, 307:47I-473.

28. Dyer MA, Bremner $R$ : The search for the retinoblastoma cell of origin. Nat Rev Cancer 2005, 5:91-101.

29. Lee TC, Almeida D, Claros N, Abramson DH, Cobrinik D: Cell Cycle-Specific and Cell Type-Specific Expression of Rb in the Developing Human Retina. Invest Ophthalmol Vis Sci 2006, 47:5590-5598.

30. Huang HJS, Yee JK, Shew JY, Chen PL, Bookstein R, Friedman T, Lee EYHP, Lee WH: Suppression of the neoplastic phenotype by replacement of the RB gene in human cancer cells. Science 1988, 242:1563-1566.

31. Sumegi J, Uzvolgyi E, Klein G: Expression of the RB gene under the control of MuLV-LTR suppresses tumorigenicity of WERI-Rb-27 retinoblastoma cells in immunodefective mice. Cell Growth Differ 1990, I:247-250.

32. Xu HJ, Sumegi J, Hu SX, Banerjee A, Uzvolgyi E, Klein G, Benedict WF: Intraocular tumor formation of $\mathbf{R B}$ reconstituted retinoblastoma cells. Cancer Res 1991, 5 I:448I-4485.

33. Madreperla SA, Whittum-Hudson JA, Prendergast RA, Chen PL, Lee $\mathrm{WH}$ : Intraocular tumor suppression of retinoblastoma genereconstituted retinoblastoma cells. Cancer Res 1991, 5I:638I-6384

34. Chen PL, Chen Y, Shan B, Bookstein R, Lee WH: Stability of retinoblastoma gene expression determines the tumorigenicity of reconstituted retinoblastoma cells. Cell Growth Differ 1992, 3:119-125.

35. Muncaster MM, Cohen BL, Phillips RA, Gallie BL: Failure of RB I to reverse the malignant phenotype of human tumor cell lines. Cancer Res 1992, 52:654-661.

36. Banerjee A, Xu HJ, Hu SX, Araujo D, Takahashi R, Stanbridge EJ, Benedict WF: Changes in growth and tumorigenicity following reconstitution of retinoblastoma gene function in various human cancer cell types by microcell transfer of chromosome 13. Cancer Res 1992, 52:6297-6304.

37. Cherry SR, Biniszkiewicz D, van Parijs L, Baltimore D, Jaenisch R: Retroviral expression in embryonic stem cells and hematopoietic stem cells. Mol Cell Biol 2000, 20:7419-7426.

38. Pfeifer A, Ikawa M, Dayn Y, Verma IM: Transgenesis by lentiviral vectors: lack of gene silencing in mammalian embryonic stem cells and preimplantation embryos. Proc Natl Acad Sci U S A 2002, 99:2। 40-2। 45

39. Horowitz JM, Park SH, Bogenmann E, Cheng JC, Yandell DW, Kaye FJ, Minna JD, Dryja TP, Weinberg RA: Frequent inactivation of the retinoblastoma anti-oncogene is restricted to a subset of human tumor cells. Proc Natl Acad Sci U S A 1990, 87:2775-2779.

40. Otterson GA, Chen W, Coxon AB, Khleif SN, Kaye FJ: Incomplete penetrance of familial retinoblastoma linked to germ-line mutations that result in partial loss of RB function. Proc Natl Acad Sci U S A 1997, 94: I2036-12040.

41. Hinds PW, Mittnacht S, Dulic V, Arnold A, Reed SI, Weinberg RA: Regulation of retinoblastoma protein functions by ectopic expression of human cyclins. Cell 1992, 70:993-1006.

42. Gudas JM, Payton M, Thukral S, Chen E, Bass M, Robinson MO, Coats S: Cyclin E2, a novel GI cyclin that binds Cdk2 and is aberrantly expressed in human cancers. Mol Cell Biol 1999, 19:612-622.

43. Hurford RK, Cobrinik D, Lee MH, Dyson N: pRB and pl 07/pI30 are required for the regulated expression of different sets of E2F-responsive genes. Genes Dev 1997, I I: | 447- I 463.

44. Mulligan GJ, Wong J, Jacks $\mathrm{T}: \mathbf{p} / \mathbf{3 0}$ is dispensable in peripheral T lymphocytes: evidence for functional compensation by p 107 and pRB. Mol Cell Biol I998, I 8:206-220.

45. Herrera RE, Sah VP, Williams BO, Makela TP, Weinberg RA, Jacks T: Altered cell cycle kinetics, gene expression, and $G I$ restriction point regulation in $\mathbf{R b}$-deficient fibroblasts. Mol Cell Biol 1996, 16:2402-2407.

46. Goodall J, Wellbrock C, Dexter T], Roberts K, Marais R, Goding CR: The Brn-2 transcription factor links activated BRAF to melanoma proliferation. Mol Cell Biol 2004, 24:2923-293I.

47. Rowan S, Cepko CL: A POU factor binding site upstream of the Chxlo homeobox gene is required for Chxlo expression in subsets of retinal progenitor cells and bipolar cells. Dev Biol 2005, 28 I:240-255.

48. Knudson A: Retinoblastoma: teacher of cancer biology and medicine. PLoS Med 2005, 2:e349.

49. Nikitin AY, Juarez-Perez MI, Li S, Huang L, Lee WH: RB-mediated suppression of spontaneous multiple neuroendocrine neoplasia and lung metastases in $\mathbf{R b}+/-$ mice. Proc Natl Acad Sci U S A 1999, 96:3916-3921.

50. Benevolenskaya EV, Murray HL, Branton P, Young RA, Kaelin WG Jr.: Binding of pRB to the PHD protein RBP2 promotes cellular differentiation. Mol Cell 2005, 18:623-635

5I. Schreiber E, Himmelmann A, Malipiero U, Tobler A, Stahel R, Fontana $A$ : Human small cell lung cancer expresses the octamer DNA-binding and nervous system-specific transcription factor N-Oct 3 (brain-2). Cancer Res 1992, 52:6121-6124.

52. Thomson JA, Murphy K, Baker E, Sutherland GR, Parsons PG, Sturm RA, Thomson F: The brn-2 gene regulates the melanocytic phenotype and tumorigenic potential of human melanoma cells. Oncogene 1995, I 1:691-700.

53. Sugitani $Y$, Nakai S, Minowa O, Nishi M, Jishage K, Kawano H, Mori $\mathrm{K}$, Ogawa $\mathrm{M}$, Noda T: Brn-I and Brn-2 share crucial roles in the production and positioning of mouse neocortical neurons. Genes Dev 2002, 16:1760-1765.

54. Templeton DJ, Park SH, Lanier L, Weinberg RA: Nonfunctional mutants of the retinoblastoma protein are characterized by defects in phosphorylation, viral oncoprotein association, and nuclear tethering. Proc Natl Acad Sci U S A I991, 88:3033-3037.

55. Kaelin WG Jr., Pallas DC, DeCaprio JA, Kaye FJ, Livingston DM: Identification of cellular proteins that can interact specifically with the T/EIA-binding region of the retinoblastoma gene product. Cell 1991, 64:521-532.

56. Amendola M, Venneri MA, Biffi A, Vigna E, Naldini L: Coordinate dual-gene transgenesis by lentiviral vectors carrying synthetic bidirectional promoters. Nat Biotechnol 2005, 23: I08-I I6.

57. Naviaux RK, Costanzi E, Haas M, Verma IM: The pCL vector system: rapid production of helper-free, high-titer, recombinant retroviruses. J Virol 1996, 70:570I-5705.

58. Burns JC, Friedmann T, Driever W, Burrascano M, Yee JK: Vesicular stomatitis virus $\mathbf{G}$ glycoprotein pseudotyped retroviral vectors: concentration to very high titer and efficient gene transfer into mammalian and nonmammalian cells. Proc Natl Acad Sci U S A 1993, 90:8033-8037.

59. Zufferey R, Nagy D, Mandel RJ, Naldini L, Trono D: Multiply attenuated lentiviral vector achieves efficient gene delivery in vivo. Nat Biotechnol 1997, 1 5:87|-875. 